\title{
Diz avasküler nekrozu
}

\section{Avascular necrosis of the knee}

\author{
Oğuzhan Korkmaz ${ }^{1}$ Figen Koçyiğit ${ }^{2}$, Ersin Kuyucu ${ }^{1}$ \\ ${ }^{1}$ İstanbul Medipol Üniversitesi Tıp Fakültesi, Ortopedi ve Travmatoloji Anabilim Dalı, İstanbul \\ ${ }^{2}$ İstanbul İstinye Üniversitesi Tıp Fakültesi, Fiziksel Rehabilitasyon ve Tıp Anabilim Dalı, İstanbul
}

\begin{abstract}
Avasküler nekroz çeşitli nedenlere bağlı olarak eklem artrozuna kadar gidebilen yıkıcı bir hastalıktır. Kalça ekleminden sonra en sık tuttuğu eklem olan diz ekleminde avasküler nekroz üç kategoride incelenebilir: spontan diz osteonekrozu (SPONK), sekonder osteonekroz (ON) ve artroskopi sonrası ON. Osteonekroz kategorilerinden bağımsız olarak, bu hastalığın tedavisi daha fazla ilerlemeyi durdurmayı veya dizin son dönem artritinin başlangıcını geciktirmeyi amaçlamaktadır. Bununla birlikte, önemli bir eklem yüzeyi çökmesi meydana geldiğinde veya dejeneratif artrit belirtisi olduğunda, eklem artroplastisi en uygun tedavi seçeneğidir. Halen, cerrahi dışı tedavi seçenekleri gözlem, steroid olmayan anti-enflamatuvar ilaçlar (NSAID’ler), ağırlık vermeden mobilize olma ve gerektiğinde analjeziden oluşur. Cerrahi müdahaleler, hastalığın kapsamına ve türüne bağlı olarak; eklem koruyucu cerrahi, tek taraflı diz artroplastisi (UKA) veya total diz artroplastisini (TKA) içerir. Genellikle sadece altta yatan subkondral kemiğin etkilendiği olgularda, kollaps öncesi ve kollaps sonrası bazı lezyonlarda eklem koruyucu prosedürler yani artroskopi, kor (core) dekompresyon, osteokondral otogreft ve kemik greftleme denenir. Tersine, şiddetli subkondral çökme meydana geldikten sonra, eklemi kurtarmaya çalışan prosedürler nadiren başarılıdır ve ağrıyı hafifletmek için eklem artroplastisi gereklidir.
\end{abstract}

Anahtar sözcükler: avasküler nekroz; diz; spontan diz osteonekrozu; diz ağrısı
Avascular necrosis is a devastating disease that can lead to joint arthrosis for a variety of reasons. Avascular necrosis of the knee joint, which is the most common joint after the hip joint, can be examined in 3 categories: spontaneous osteonecrosis of the knee (SONK), secondary osteonecrosis and post-arthroscopy. Regardless of the categories of osteonecrosis, the treatment of this disease is aimed at stopping further progression or delaying the onset of endstage arthritis of the knee. However, when significant joint surface collapse occurs or there is a sign of degenerative arthritis, joint arthroplasty is the most appropriate treatment option. Currently, non-operative treatment options include observation, nonsteroidal anti-inflammatory drugs (NSAIDs), weightless mobilization, and analgesia as needed. Operative interventions include joint-sparing surgery, unilateral knee arthroplasty (UKA) or total knee arthroplasty (THA), depending on the extent and type of the disease. Generally, when only the underlying subchondral bone is affected, joint preserving procedures, namely arthroscopy, core decompression, osteochondral autograft and bone grafting, are tried in some lesions before and after collapse. Conversely, once severe subchondral collapse has occurred, procedures attempting to save the joint are rarely successful and joint arthroplasty is required to relieve pain.

Key words: avascular necrosis; knee; spontaneous osteonecrosis of the knee; knee pain
D iz avasküler nekrozu ilk kez 1968 yılında Ahlbäck ve ark. tarafindan dizin ileri derece artrozuna sebebiyet verebilen yıkıcı bir hastalık olarak tanımlanmıştır. ${ }^{[1]}$ Diz eklemi, kalça ekleminden sonra avasküler nekroz açısından en sık etkilenen ikinci bölgedir. ${ }^{[2]}$

Diz ostenekrozu üç kategoride incelenebilir; 1) Spontan diz osteonekrozu (SPONK). 2) Sekonder diz osteonekrozu. 3) Artroskopi sonrası diz osteonekrozu. ${ }^{[2]}$ SPONK, dizin en sık görülen ostenekroz formu olup, 50 yaş üstü hastalarda daha yüksek prevalans göstermektedir. ${ }^{[3]}$ Buna karşın sekonder osteonekroz ise daha genç hastalarda genellikle iki taraf tutulumlu ve altta yatan bir nedene bağlı olarak ortaya çıkar. Artroskopi sonrası ostenekroz ise en nadir görülen formu olup her iki kondili tutan, en sık menisektomi sonrasında görülen ve artroskopi hastalarının ortalama \%4'ünde görülen formudur. ${ }^{[4]}$ Semptomlar genellikle benzer olup tanıda ve tedavide farklılıklar olduğundan bu 3 durumu birbirinden ayırt etmek zor ancak oldukça önemlidir (Tablo 1).

- Illetişim adresi: Dr. Oğuzhan Korkmaz, Göztepe Mah. Metin Sokak No: 3, Medipol Mega Hastaneler Kompleksi, Bağcılar, İstanbul Tel: 0507 - 6638007 e-posta: droguzhankorkmaz@gmail.com

- Geliș tarihi: 4 Eylül $2020 \quad$ Kabul tarihi: 24 Eylül 2020 
Tablo 1. SPONK, sekonder ve artroskopi sonrası gelişen osteonekrozun genel özelliklerinin karşılaştırılması

\begin{tabular}{|c|c|c|c|}
\hline Özellik & SPONK & Sekonder osteonekroz & Artroskopi sonrası osteonekroz \\
\hline Yaş & $>60$ & $<45$ & Anlamlı dağılım farkı yok. \\
\hline Cinsiyet & $K>E$ & Etiyolojiye göre farklılık gösterir. & Anlamlı dağılım farkı yok. \\
\hline Ağrı & Ani başlar. & Sinsidir. & Ani başlar. \\
\hline Tutulum & Genellikle tek taraflıdır. & >\%80 bilateraldir. & Genellikle tek taraflıdır. \\
\hline Lezyonun lokasyonu & Epifiz & Epifiz, metafiz, diyafiz & Epifiz \\
\hline Diğer eklem tutulumu & Yok & $>\% 90$ farklı eklem tutulumu mevcuttur. & Yok \\
\hline Etiyolojik ajan & Bilinen yok & Kortikosteroid, alkol vb. & Artroskopi \\
\hline Altta yatan hastalık & Yok & $\begin{array}{l}\text { SLE, orak hücreli (sickle cell) anemi, } \\
\text { trombofili... }\end{array}$ & Yok \\
\hline Patolojik bulgu & İyileşen kırık paterni & Nekrotik kemik & Nekrotik kemik, iyileşen kırık \\
\hline Prognoz & $\begin{array}{l}3,5 \mathrm{~cm}^{2} \text { 'den küçük lezyonlar } \\
\text { kendiliğinden iyileşebilir. } \\
3,5 \mathrm{~cm}^{2} \text { 'den büyük lezyonlar } \\
\text { ilerleme eğilimindedir. }\end{array}$ & $\begin{array}{l}\text { Ağrısız lezyonlar ilerleme eğiliminde değildir. } \\
\text { Ağrılı lezyonlara cerrahi önerilir. } \\
\text { Ameliyatsız tedavi başarısı düşüktür. }\end{array}$ & $\begin{array}{l}\text { Manyetik rezonans (MR) } \\
\text { görüntülemede lezyonların } \\
\text { çoğunluğu geri dönüşsüzdür. } \\
\text { Erken evrede konservatif tedavi. }\end{array}$ \\
\hline
\end{tabular}

\section{SPONK}

\section{Etiyoloji ve Patofizyoloji}

SPONK, sıklıkla 60 yaş üstü hastalarda görülmekte olup, kadınları erkeklere göre daha çok tutar ve sıklıkla tek taraf tutulumuyla gider. ${ }^{[5]}$ SPONK, genellikle medial femoral kondili etkileyen fokal, subkondral osteokondral lezyon olarak da tanımlanmaktadır. ${ }^{[6]}$ Patofizyolojik olarak ilk tanımlamalarda SPONK'un nekroz ile sonuçlanacak iskemiye sekonder oluştuğu düşünülmekteydi. Günümüzde ise SPONK'un, osteopenik kemikteki subkondral yetmezlik kırıklarına bağlı oluştuğu düşünülmektedir. ${ }^{[6]}$ Oluşan yetmezlik kırıklarına bağlı intraosseöz yoğunluğun artması fokal iskemi ve nihai nekroz ile sonuçlanmaktadır. ${ }^{[6]}$ Bununla birlikte hastalığın sıklıkla etkilediği popülasyonun 60 yaş üstü kadın hastalar olduğu bilinmekte ve bu hasta grubunda, düşük kemik mineral yoğunluğu ile SPONK insidansı arasında pozitif bir ilişki olduğunu gösterilmiştir. ${ }^{[7]}$ Bu nedenle, "SPONK" teriminin aslında yanlış bir isim olabileceğini ve "deplase kırık fragmanın, kemik ölümüne neden olan stabil olmayan kırı̆g”" olarak yeniden tanımlandığı öne sürülmüşstür. ${ }^{[8]}$

\section{Klinik ve Tanı}

SPONK'si olan hastalar genellikle travma ile tetiklenmeyen ani başlangıçı medial taraflı diz ağrısı ile başvururlar. Fizik muayenede en sık rastlanan bulgu medial femoral kondil üzerinde fokal hassasiyet ve ağrıdır. ${ }^{[9]}$ Ağrının özelliği hareket ile ve gece artmasıdır. Bu da günlük pratikte sık karşılaştığımız medial menisküs yırtığı sonrası kliniği ile karışabilmektedir. ${ }^{[2]}$

İlk değerlendirmede diz anteroposterior (AP), lateral ve oblik radyografiler alınmalıdır. Ancak hastalığın erken seyrinde direkt grafi bulguları sıklıkla negatiftir ve bazı durumlarda klinik semptomların tüm süresi boyunca negatif kalabilir. ${ }^{[10]}$ Geç evre hastalığın tipik radyografik bulguları arasında, radyolusens artışı veya etkilenen kondilin düzleşmesi bulunur. Özellikle erken evre hasta da kemik ödeminin saptanmasında yüksek duyarlılığı nedeniyle manyetik rezonans (MR) görüntüleme önerilir. ${ }^{[10]}$ MR'de tipik olarak erken evre ostenekrozu gösteren, T2 ağırlıklı görüntülerde subkondral alanda düşük sinyal yoğunluğu içeren alanların olması, fokal epifiz kontur depresyonları ve etkilenen kondile uzanan düşük sinyal yoğunluğu görülür (Şekil 1). Kemik sintigrafisi, etkilenen kondilde artmış tutulumu gösterebilir, ancak bu yöntem hastalığın tanımlanmasında MR'den daha az duyarlıdır. ${ }^{[11]}$

Koshino sınıflandırması, SPONK için 1979'da tanımlanan ilk sınıflandırmadır (Tablo 2). Koshino evreleme sisteminde klinik ve radyografik bulgulara dayanan dört aşama vardır. ${ }^{[12]}$ Diz semptomları olan, ancak normal radyografik bulguları evre I olarak sınıflandırılır. Evre II, osteoskleroz ile çevrili yassılaşan ve subkondral radyolusensleri olan ağılık taşıyan alanı gösterir. Evre III, radyoaktif maddelerin etkilenen bölge etrafına yayılmasını ve subkondral çökmeyi gösterir. Evre IV, kondiller çevresinde osteoskleroz ve osteofit oluşumu ile dejeneratif evredir. 


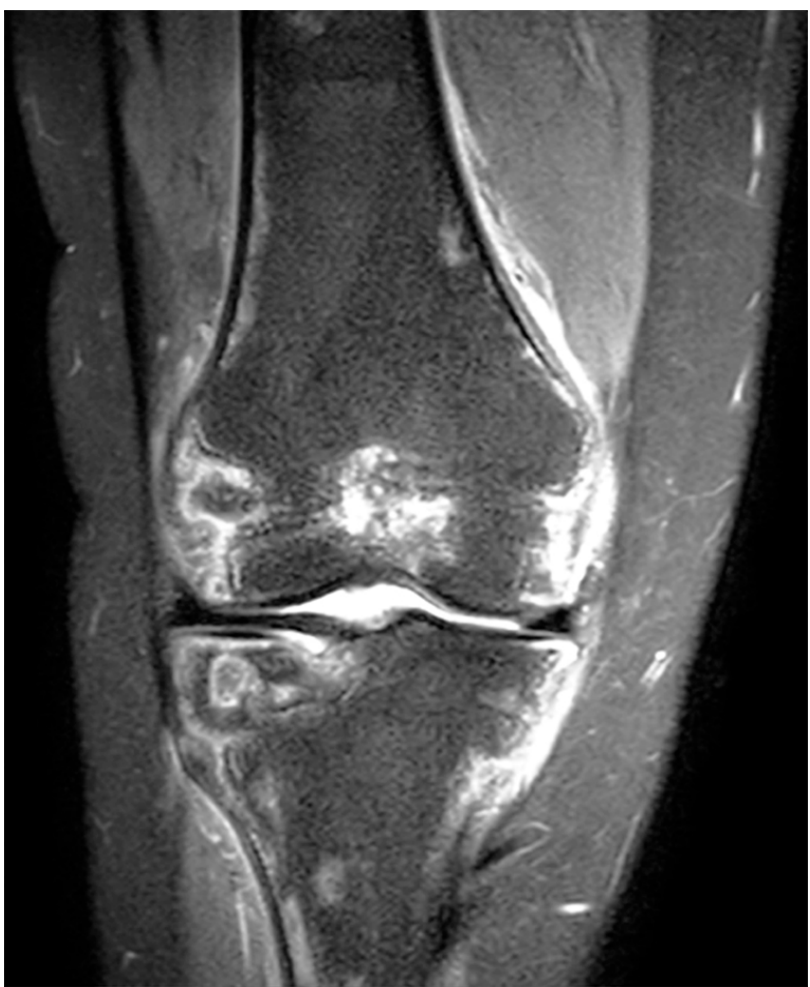

Şekil 1. T2 ağırlıklı sekansta görülen fokal düşük sinyal alanları (ALL tanılı hastada yoğun kortikosteroid kullanımı sonrası gelişen sekonder osteonekroz görüntüsü olup, radyolojik olarak MR bulgularını göstermek amacıyla kullanılmıştır).

\section{Tedavi}

SPONK'ta tedavi semtomların şiddetine ve tutulum evresine göre konservatif ya da cerrahi olarak şekillendirilebilir. Tedavi kararı lezyonun, anterior-posterior radyografideki en büyük geniş̧lik ve lateral radyografideki en büyük uzunluk ölçülerek alınan osteonekrotik alanın büyüklüğüne dayanmaktadır. Üç buçuk santimetre kareden küçük lezyonlar genellikle cerrahi olmayan tedavi ile geriler, orta büyüklükteki lezyonlar (3,5 ila 5,0 santimetre kare) gerileme yapabilir ve 5 santimetre kareden büyük lezyonlar genellikle kondiler çökmeye (kollapsa) yol açar (Şekil 2). ${ }^{[2,13,14]}$

\section{Cerrahi Olmayan Tedavi}

Konservatif tedavi genellikle 3,5 santimetrekareden küçük olan lezyonlar için kullanılır. Bu tedavi nonsteroid anti-enflamatuvar ilaçlar, etkilenen ekstremiteye yük vermekten kaçınma ve analzejikler ile sağlanır. Bu tedavinin erken evre SPONK saptanan hastalarda 3-8 ay içerisinde semptomların gerilediğini ve MR'de normale dönüş olduğu bildirilmiştir. ${ }^{[15]}$ Bisfosfonatlar ise tipik olarak maligniteler ve osteoporozda kullanılan ilaçlardır. Bisfosfonatlar osteoklastlar üzerinden etki ederek kemik rezorpsiyon hızını inhibe ederler. Doğal olarak nekrotik kemiğin rezorbe edilmesini inhibe ederek subkondral çökmeleri önlemesi sebebiyle femur başı avasküler nekrozunda kullanılmaktadır.

Tablo 2. Koshino sınıflaması ${ }^{[12]}$

\begin{tabular}{clll}
\hline Evre & Radyografi & Direkt bakı & Klinik \\
\hline I & Normal & Özellik yok & Dizde ağrı \\
II & Subkondral radyolüsensite artışı & Eklem yüzünde düzleşme & Özellik yok \\
III & Skleroz ile çevrili radyolüsen alan, kemikte kalsifıye çökmüş alan & Kalkmış kıkırdak \pm serbest cisim & Özellik yok \\
IV & Yaygın osteofit ve skleroz & Özellik yok & Özellik yok
\end{tabular}

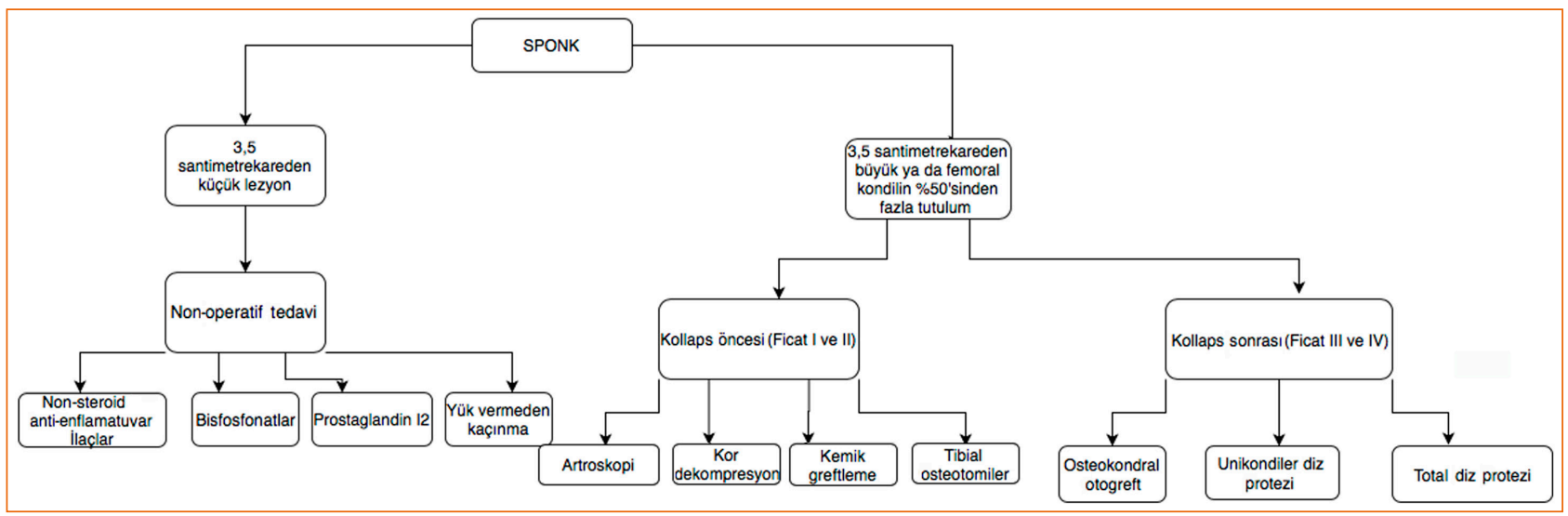

Şekil 2. SPONK'de lezyonun büyüklüğüne göre tedavi algoritması (SPONK, spontaneous osteonecrosis of the knee). ${ }^{[14]}$ 
Jureus ve ark., SPONK'si olan 17 hastada 6 ay boyunca haftada bir kez $70 \mathrm{mg}$ alendronat kullanımını değerlendirdiler. Hastaların sadece \%18'inde (17'sinden üçünde) subkondral çökmenin devam ettiğini göstermişlerdir.[16]

\section{Cerrahi Tedavi}

Konservatif tedaviye 3 ay ve daha uzun süre yanıt vermeyen hastalarda ya da 3,5 santimetrekareden büyük lezyonu olan hastalarda cerrahi tedavi düşünülmelidir. Cerrahi tedavide ilk önce eklem koruyucu tedaviler düşünülmelidir. SPONK'un erken evre lezyonlarında artroskopik debridman ve/veya artroskopik mikrokırık uygulanabilir. ${ }^{[17,18]}$ Ayrıca dirençli SPONK hastaları için kor dekompresyon semptomatik ve radyolojik iyileşmeyi sağlaması açısından iyi bir seçenek olabilir. ${ }^{[19]}$ Kor dekompresyonu takiben 3 hafta sürecek, işlem yapılan taraf ekstremiteye parsiyel yük vererek yürüme, kuadriseps güçlendirme ve diğer diz çevresi kasları güçlendirme gibi egzersizler fonksiyonel sonuç açısından öneme sahiptir. Bununla birlikte subkondral çökme ile giden hastalar osteokondral otogreftlemeden yarar görebilirler. Osteokondral otogreftleme mekanik olarak daha dayanıklı bir kemik destek doku oluşturması ve çökmüş, ölü dokunun çıkarılması gibi avantajlara sahiptir. ${ }^{[20]}$ Yüksek tibial osteotomi protezin uygulanamayacağı genç ve aktif hastalarda uygun bir seçenektir. Proksimal tibial metafizer alana yapalıcak osteotomi ile bu bölgeyi dekomprese ederek iyileşme potansiyelini yükseltir. SPONK'da tutulum genelde medial femoral kondilde olduğundan medialden açık kama ile valgizasyon uygun bir seçenek olabilir. [21] Eklemde ileri derecede hasarlanma mevcut ise eklem koruyucu seçeneklerden eklem rekonstrüksiyonu seçeneklerine doğru yönelmek gerekebilir. SPONK'ta genellikle tek kondil tutulumu olduğundan unikompartmantal (unikondiller) diz artroplastisi (UKA) iyi bir seçenek olarak düşünülebilir. Tek kompartman osteoartirtlerinde fonksiyonel sonuçları anlamlı derece yüksek olan UKA tek kondil tutulumlu olgularda kemik stoğu korumak adına iyi bir seçenektir. ${ }^{[22]}$ Birden fazla kompartmanın tutulduğu durumlarda ise total diz artroplastisi düşünülmelidir. [23]

Özet olarak tedavi kararı osteonekrotik lezyonun büyüklüğüne dayanmaktadır; 3,5 santimetrekareden küçük lezyonlar cerrahi olmayan tedavi ile gerileyebilir, 3,5 santimetrekareden büyük lezyonlar için muhtemelen cerrahi müdahale gerekecektir (Şekil 2). Hasta çökme öncesi dönemdeyse cerrahi müdahale yapılırken, eklem koruyucu prosedürler denenmelidir, ancak çökme meydana gelmişse eklem artroplastisini düşünmelidir.

\section{SEKONDER OSTEONEKROZ}

\section{Etiyoloji ve Patofizyoloji}

Dizde sekonder veya atravmatik osteonekroz görülme sıklığı, kalça osteonekrozu insidansından yaklaşık \%90 daha azdır. Genellikle 45 yaşından küçük hastaları etkiler ve sıklıkla çok sayıda eklemi etkileyen çoklu lezyonları içerir. SPONK'dan farklı olarak, sekonder osteonekroz hem femoral kondilleri hem de tibia'nın epifizi, diyafizi ve metafizini içerebilir (Tablo 1). Bu patolojiye sahip hastaların çoğunda bilateral tutulum vardır (>\%80). Bununla birlikte, spontan osteonekroz gibi, bir kadın hâkimiyeti vardır. ${ }^{[2]}$ Sekonder osteonekroz, doğrudan bir başka patolojiye (orak hücre hastalığı, Caisson hastalığı, Gaucher hastalığı, myeloproliferatif bozukluklar, vb.) veya dolaylı olarak risk faktörlerine (alkol, kortikosteroidler, tütün, obezite) bağlı olarak gelişebilir. Sekonder osteonekroz için en yaygın iki risk faktörü kortikosteroid kullanımı ve aşırı alkol kullanımıdır (>\%90). ${ }^{[2]}$ Son kanıtlar, kortikosteroidlerin ve alkolün kemik iliği yağ hücrelerinin hipertrofisine neden olarak kemik iskemisine yol açabilecek kemik içi basıncın artmasına neden olabileceği yönündedir. Tütün kullanımı, orak hücre hastalığı ve diğer koagülopatik bozukluklar gibi diğer risk faktörleri çoğunlukla vazo-oklüzif etkilere sahiptir. Sigara içiminin oksidatif hasara ek olarak vazokonstrüksiyona neden olduğu bilinmektedir, bu nedenle damar endotelini tehlikeye atarak aterosklerozise yatkınlığı artırır. Orak hücre hastalığında bulunan düzensiz şekilli, deforme olabilen kırmızı kan hücrelerinin vasküler endotel dokuya yapışması ile birlikte kümelenmesi (hücre hasarı) olasılığı daha yüksektir. Benzer şekilde, dekompresyon hastalığında (Caisson hastalığı) görülen azot gazı embolisi direkt olarak vasküler oklüzyona neden olabilir. Bu durumların vücudun başka yerlerinde vazo-oklüzyona neden olduğu gibi, kemikte vazo-oklüzyona neden olabilir ve iskemiye yol açabilir.

\section{Klinik ve Tanı}

Spontan osteonekrozda ani ağrı başlangıcının aksine, sekonder osteonekrozu olan hastalar genellikle etkilenen bölge üzerinde kademeli bir ağrı başlangıcı tanımlayacaktır. Ağrı çoğunlukla femoral kondil üzerinde bulunur, ancak yaklaşık \%20 oranında tibial kondil de dâhil olabilir. Sekonder osteonekroz sıklıkla birden fazla eklem içerdiğinden hastalar diğer eklemlerdeki ağrıdan da şikâyet edebilirler. ${ }^{[24]}$

SPONK'a benzer şekilde, AP ve lateral direkt radyografiler ve MR, sekonder osteonekroz tanısının temelidir. Tek bir lezyon yerine çoklu lezyonlar görülebilir ve olguların \%80'inde bilateral diz tutulumu görülür. Ek olarak, SPONK lezyonları çoğunlukla kemiğin epifizini tutarken, sekonder osteonekroz olgularında tutulum 
femurun epifizinde, metafizinde veya diyafizinde olabilir. Sekonder osteonekroz için iki aşamalı sınıflama sistemi kullanılmaktadır; birincisi SPONK için uyarlanan Koshino sınıflaması ve diğeri de aslen femur başı avasküler nekrozu için tanımlanan Modifiye Ficat ve Arlet sınıflamasının diz için uyarlanmış halidir. ${ }^{[25]}$ Düz radyografilere dayanan bu sınıflama sisteminde ve eklem-daralması, subkondral çöküş ve trabeküler paterni temel alan dört aşama içerir (Tablo 3 ). Evre I ve II normal bir eklem boşluğuna sahiptir ve subkondral çökme yoktur, ancak evre II'de trabeküllerde skleroz görülmeye başlanır. Evre III, subkondral çökme ile normal veya hafifçe dar bir eklem boşluğuna ve "hilal işareti" olarak adlandırılan trabeküllerin sekestre edilmiş bir görünüme sahiptir. Evre IV'te hem eklem aralığında daralma hem de subkondral kollaps görülür.

\section{Tedavi}

Sekonder osteoartrozda tedavi kararını verdirecek olan semptomların durumudur. Çünkü asemptomatik giden hastalarda prognoz daha iyi seyrederken semptomu olan hastalarda cerrahi tedavi gereksinimi artmaktadır. Asemptomatik hastalarda cerrahi olmayan tedavi seçenekleri $\% 80$ oranında cerrahi gereksinimden kaçınılabilir (Şekil 3). ${ }^{[2]}$

\section{Cerrahi Olmayan Tedavi}

Sekonder osteoartrozda genellikle yaygın tutulum olduğu için cerrahi tedavi gündeme gelmektedir. Ancak asemptomatik hastalarda konservatif tedavi denenebilir. Semptomu olmayan sekonder osteonekroz hastalarının \%80'inde cerrahi olmayan tedavi seçenekleri ile takipte klinik ve radyolojik iyileşme olurken bu oran semptomu olan hastalarda \%19 kadardır. Semptomu olan hastaların sonunda total diz artroplastisine ihtiyaç duydukları bildirilmiştir. ${ }^{[2]}$ Ayrıca epifiz tutulumu olan hastalar, metafiz ve diyafiz tutulumu olan hastalara göre daha kötü prognoz ile seyretmektedir. Yapılan çalışmalarda bisfosfonatların ve Prostaglandin I-2 (PGI-2) tedavisinin cerrahi olmayan tedavide kullanılabileceğini göstermektedir. Jäger ve ark.'nın sekonder diz osteonekrozu olan ve bisfosfonatlar ile tedavi edilen 28 hastayı değerlendirdikleri çalışmada; başlangıçta pamidronat $120 \mathrm{mg}$ i.v. iki hafta boyunca 3 ila 4 perfüzyona bölünmüş, ardından 4 ila 6 ay boyunca haftada $70 \mathrm{mg}$ oral alendronat verilmiştir. ${ }^{[26]}$ Yazarlar, VAS'ın (görsel analog skorun) 4 ila 6 haftada 8 puandan 5 puana anlamlı bir azalma olduğunu göstermişlerdir; 6 ayda ortalama VAS'ta \%80 azalma olmuştur. Yazarlar, 6 aylık bir takipte 15 kişide semptomların tam olarak gerilediğini, sadece altı hastada minimal rezidüel ağrı olduğunu ve 18 hastanın MR görüntülerinde kemik

Tablo 3. Femur başında kullanılan Koshino ve modifiye Ficat-Arlet sınıflamasının diz için uyarlanmış hali[25]

\begin{tabular}{|c|c|c|c|c|c|c|}
\hline \multirow[t]{2}{*}{ Evre } & \multicolumn{3}{|l|}{ Koshino sınıflaması } & \multicolumn{3}{|c|}{ Ficat-Arlet sınıflaması } \\
\hline & Radyografi & Direkt bakı & Klinik & Eklem mesafesi & Kondil şekli & Trabekülarite \\
\hline I & Normal & Özellik yok & Dizde ağrı & Normal & Normal & Benekli osteoporoz alanları \\
\hline II & $\begin{array}{l}\text { Subkondral radyolüsensite } \\
\text { artışı }\end{array}$ & $\begin{array}{l}\text { Eklem yüzünde } \\
\text { düzleşme }\end{array}$ & Özellik yok & Normal & Normal & Skleroz \\
\hline III & $\begin{array}{l}\text { Skleroz ile çevrili radyolüsen } \\
\text { alan, kemikte kalsifiye } \\
\text { çökmüş alan }\end{array}$ & $\begin{array}{l}\text { Kalkmış kıkırdak } \\
\pm \text { serbest cisim }\end{array}$ & Özellik yok & $\begin{array}{l}\text { Normal veya } \\
\text { hafif daralmış }\end{array}$ & Subkondral & Sekestrum \\
\hline IV & Yaygın osteofit ve skleroz & Özellik yok & Özellik yok & Daralmış & Kollaps & Yaygın harabiyet \\
\hline
\end{tabular}

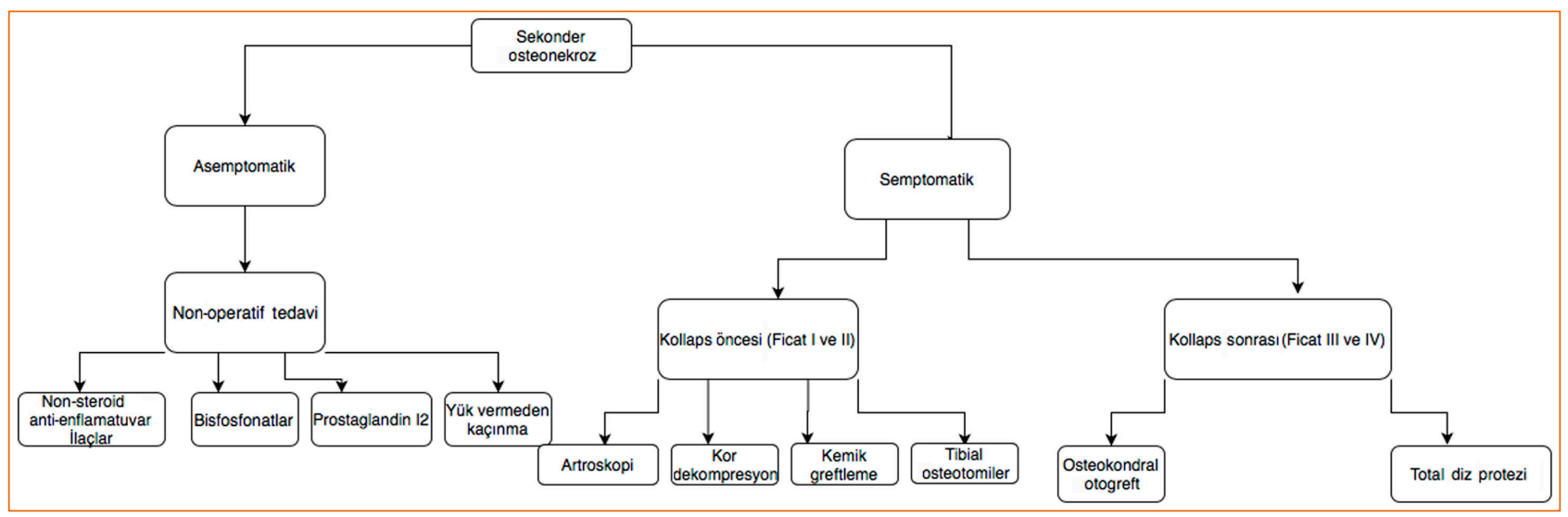

Şekil 3. Sekonder ON'de lezyonların semptomatik veya asemptomatik oluşuna göre tedavi algoritması. ${ }^{[14]}$ 
iliği ödeminin tamamen düzeldiğini kaydettiler. Benzer şekilde Jäger ve ark. prostaglandin I-2 uygulamasından sonra hastaların kemik iliği ödemi ve erken avasküler nekroz aşamalarında ağrı, fonksiyon ve radyolojik sonuçlarda anlamlı düzelme olduğunu bulmuşlardır.

\section{Cerrahi Tedavi}

Sekonder osteonekrozun subkondral çökme öncesi aşamalarında eklem artroplastisini önlemek veya ertelemek için artroskopi, kor dekompresyonu, osteokondral otogreft ve kemik greftleme gibi eklem koruyucu cerrahi yapılabilir. ${ }^{[8]}$

Artroskopi öncelikle menisküs yırtı̆̆ı veya osteokondral defekt gibi diğer diz patolojileri varsa önerilir. Artroskopi, bu kusurların ele alınmasına ve eklemdeki kemiğin durumunun doğrudan görüntülenmesine izin verecektir. Kor dekompresyon ve osteokondral allogreft gibi diğer tedavi edici işlemler artroskopi sırasında da yapılabilir. ${ }^{[23]}$ SPONK'da olduğu gibi core dekompresyon, subkondral çökme olmadan sekonder osteonekrozda başarıyla kullanılabilir. ${ }^{[24,26,27]}$

Erken evre osteonekrozu olan hastalarda kemik greftlemesi de kullanılmıştır. ${ }^{[28]} \mathrm{Bu}$ prosedürde, osteonekrotik lezyon eksize edilir ve daha sonra kemik defekti, çökmeyi önlemek ve femoral kondilin doğal anatomisini yeniden oluşturmak için kemik otogreft veya taze dondurulmuş allogreft ile yeniden yapılandırılır. Osteokondral allogreft transplantasyonu, büyük veya karmaşık lezyonlarda bile etkinlik gösteren ve etkilenen bölgeye olgun hiyalin kıkırdağını restore etme avantajına sahip başka bir prosedürdür.

SPONK hastalarına benzer şekilde, total diz artroplasitisi konservatif önlemleri başarısız olan ve subkondral kemik çökmesi (Ficat evre III ve IV hastalı̆̆ı) ile başvuran hastalarda en uygun cerrahi seçenektir. Tersine, unikondiller diz artroplasitisi, birden fazla kondilin sık tutulmasından dolayı sekonder osteonekroz için önerilmez. ${ }^{[8]}$ Birçok çalışma total diz artroplastisinin mükemmel sonuçlarını göstermiştir. ${ }^{[29]}$

\section{ARTROSKOPI SONRASI OSTEONEKROZ}

\section{Etiyoloji ve Patofizyoloji}

Son dönemlerde özellikle artroskopik girişimlerin artması ile daha fazla karşılaşılan ancak diz osteonekrozları arasında en nadir görülen gruptur (Tablo 1). Nadir görülmesinin yanında artroskopik girişimlerden sonra insidansı \%4'e kadar çıkmaktadır. ${ }^{[4]}$ Artroskopi sonrası osteonekroz genellikle rutin kondroplasti ve menisektomi sonrası görülür. ${ }^{[30,31]}$ Lazer destekli menisektomi ve ön çapraz bağ rekonstrüksiyonu sonrası genellikle insidansı daha düşüktür. ${ }^{[32]}$ Etiyoloji üzerine çeşitli teoriler vardır. Pape ve ark., meniskektomi sonrası diz biyomekaniğinin değişmesine ve bu da temas basınçlarının artmasına neden olarak, yetmezlik kırıklarına sinoviyal sıvının intraosseöz sızıntısına ve nihayetinde osteonekroz gelişimine neden olabileceğini ileri sürdüler. ${ }^{[33]}$ Diğer yazarlar lezyonu aslında geleneksel olarak tarif edildiği gibi saf osteonekroz olarak değil subkondral bir kırık olarak tanımlamışlardır. ${ }^{[31]}$ Bir başka teori de osteonekroza fotoakustik veya radyofrekans (RF) kullanımına bağı termal etkinin sebep olduğu görüşüdür. ${ }^{[34]}$ Ancak Cetik ve ark., RF enerjisini açıkça osteonekrozun bir nedeni olarak tanımlayamamakla birlikte, artroskopik kondroplasti için kullanılan bipolar RF enerjisinin uygun cerrahi tekniklerin uygulanması durumunda subkondral osteonekroza neden olmadığı sonucununu bildirmişleridir. ${ }^{[4]}$

\section{Klinik ve Tanı}

Kadın ve erkek cinsiyetin eşit derecede etkilenmiş olduğu bildirilmektedir ve en yaygın olarak yaşamın beşinci dekadında ortaya çıkmaktadır. Medial femoral kondilin en sık etkilendiği bildirilir, bunu lateral femoral kondil, lateral tibial plato ve medial tibial plato izler. ${ }^{[30]}$ Bu hastalar tipik olarak sekonder osteonekrozda görülen daha yavaş başlangıcın aksine ani başlangıçı diz ağrısı ile başvururlar. Genellikle semptomlar artroskopik prosedürden yaklaşık altı ila sekiz hafta sonra başlar. ${ }^{[24]}$

Artroskopi sonrası osteonekroz şüphesi olan hastalarda dizde düz radyografiler ve MR değerlendirmesi önerilmektedir. Kemik iliği ödemi genellikle artroskopik prosedürün uygulandıktan sonra görülür ve artroskopiden önce MR bulguları normaldir. ${ }^{[8]}$ Pape ve ark. tarafından ${ }^{[32]}$ hastalık için; iki ölçüt ortaya konmuştur:

1- Ameliyat öncesi bulguların ortaya çıkmasından 4-6 hafta sonra çekilen MR bulgularının negatif olması.

2- Ameliyat sonrası dönemde uygun bir zaman aralığı içinde çekilen MR'nin pozitif olması.

\section{Cerrahi Olmayan Tedavi}

Artroskopi sonrası osteonekrozun ilk tedavisi etkilenen ekstremiteye ağılık verilmesinden kaçınılması, non-steroid anti-enflamatuvarlar ve analjeziden oluşmalıdır. Bisfosfonatların meniskektomi sonrası artroskopik osteonekrozun cerrahi dışı yönetiminde de yararlı olduğu gösterilmiştir. ${ }^{[35]}$ Kraenzlin ve ark. postartroksopik osteonekroz tanısı almış 22 hastada 120 mg intravenöz pamidronat 120 mg'yi 2 hafta boyunca 3 veya 4 doza bölerek uygulamışlar, ardından 4 ila 6 ay boyunca haftada bir oral alendronat $(70 \mathrm{mg}$ ) ile takip etmişlerdir. Bisfosfonat ile tedavinin VAS'ta 8'den 5'e 


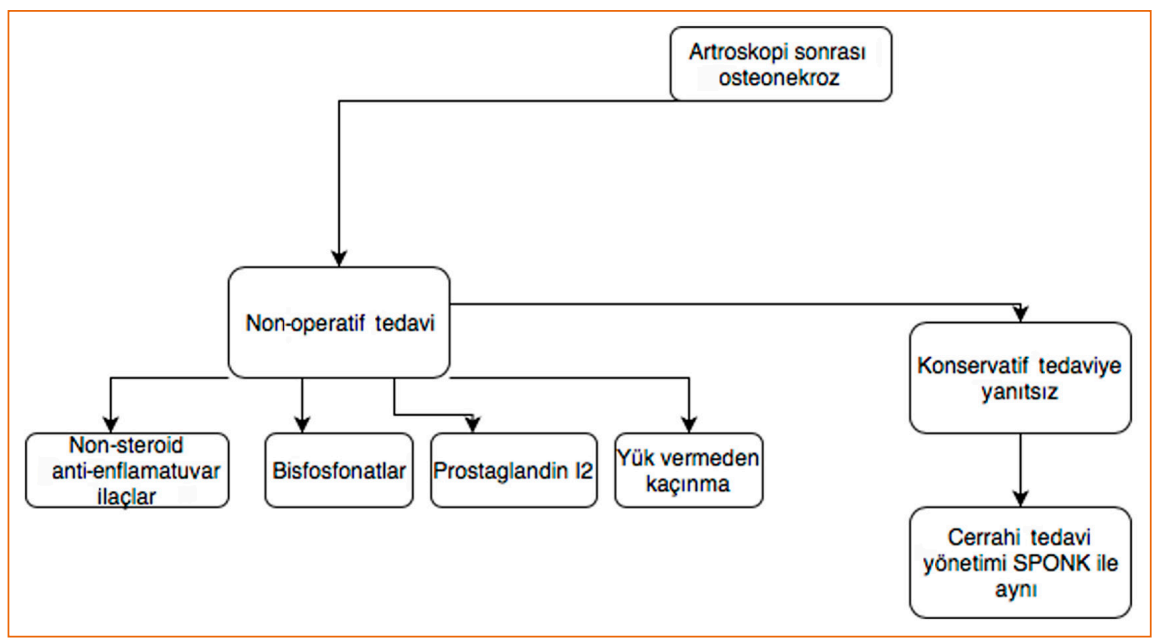

Şekil 4. Artroskopi sonrası oluşan diz ON'de tedavi algoritması (SPONK, spontaneous osteonecrosis of the knee). ${ }^{[14]}$

ve 4 ila 6 hafta sonra azaldığını gösterilmiştir. Altı ay sonra VAS \%80 azaldı. ${ }^{[36]}$ Subkondral çökmenin olmadığı aşamada cerrahi olmayan tedaviler iyi sonuç vermektedir, ancak çökme başladıysa cerrahi müdahala gerekliliği kaçınılmazdır (Şekil 4). ${ }^{[8]}$

\section{Cerrahi Tedavi}

Kor dekompresyon veya osteokondral allogreft onarımı uygulanabilecek eklem koruyucu seçenekler arasındadır. Kor dekompresyonunda başarısız olan ve halen erken evre hastalığı olan genç, aktif bireylerde yüksek tibial osteotomi de düşünülebilir. ${ }^{[24]}$ Son dönem artriti, ileri evre hastalığı veya eklem koruyucu tedavinin başarısızlığı olan hastalar için unikompartmantal veya total diz artroplastisi önerilir. Bonutti ve ark. artroskopi sonrası osteonekrozu olan ve 4'ü unikondiller ile ve $15^{\prime} i$ total diz artroplastisi ile tedavi edilen 19 hasta bildirmişlerdir. ${ }^{[34]}$ Hastaların \%95'inin, ortalama 62 aylık takipte, Diz Toplumu Skoru 80'den fazla olan iyi ve mükemmel klinik sonuçlara sahip olduğunu göstermiştir. Unikompartmantal diz artroplastisi, tek kondilde (kompartmanda) hastalığı olan hastalar için iyi bir seçenek olabilir, ancak yaygın tutulumu olanlar için, total diz artroplastisi daha iyi bir seçim olabilir.

Sonuç olarak; dizin osteonekrozu çeşitli etiyolojik nedenlerle ortaya çıkabilen nadir bir durumdur. Etiyolojik olarak farklı olsa da kliniği genelde tipiktir. MR görüntüleme tanı koymada önemli yer tutar. Hastalığın erken dönemde teşhisi, tedavi başarısı için önemlidir. Diz osteonekrozunun tedavisi, konservatif tedaviden, minimal invaziv cerrahi müdahalelere ve hatta eklem artroplastisine kadar uzanan geniş bir aralığı içerir. Erken evre hastalarda basit kor dekompresyon ağrı üzerine oldukça etkiliyken ileri evre diz ostenekrozunda total diz artroplastisi güvenilir bir tedavi seçeneğidir.

\section{KAYNAKLAR}

1. Ahlbäck S, Bauer GC, Bohne WH. Spontaneous osteonecrosis of the knee. Arthritis Rheum 1968;11(6):705-33. Crossref

2. Mont MA, Baumgarten KM, Rifai A, Bluemke DA, Jones LC, Hungerford DS. Atraumatic osteonecrosis of the knee. J Bone Joint Surg Am 2000;82(9):1279-90. Crossref

3. Pape D, Seil R, Fritsch E, Rupp S, Kohn D. Prevalence of spontaneous osteonecrosis of the medial femoral condyle in elderly patients. Knee Surg Sports Traumatol Arthrosc 2002;10(4):233-40. Crossref

4. Cetik O, Cift H, Comert B, Cirpar M. Risk of osteonecrosis of the femoral condyle after arthroscopic chondroplasty using radiofrequency: a prospective clinical series. Knee Surg Sports Traumatol Arthrosc 2009;17(1):24-9. Crossref

5. Mears SC, McCarthy EF, Jones LC, Hungerford DS, Mont MA. Characterization and pathological characteristics of spontaneous osteonecrosis of the knee. lowa Orthop J 2009;29:38-42. https://www.ncbi.nlm.nih.gov/pmc/ articles/PMC2723690/

6. Yamamoto T, Bullough PG. Spontaneous osteonecrosis of the knee: the result of subchondral insufficiency fracture. J Bone Joint Surg Am 2000;82(6):858-66. Crossref

7. Akamatsu Y, Mitsugi N, Hayashi T, Kobayashi H, Saito $\mathrm{T}$. Lowbone mineral density is associated with the onset of spontaneous osteonecrosis of the knee. Acta Orthop 2012;83(3):249-55. Crossref

8. Mont MA, Marker DR, Zywiel MG, Carrino JA. Osteonecrosis of the knee and related conditions. J Am Acad Orthop Surg 2011;19(8):482-94. Crossref

9. Lotke PA, Abend JA, Ecker ML. The treatment of osteonecrosis of the medial femoral condyle. Clin Orthop Relat Res 1982;(171):109-16. Crossref

10. Houpt JB, Pritzker KP, Alpert B, Greyson ND, Gross AE. Natural history of spontaneous osteonecrosis of the knee (SONK): a review. Semin Arthritis Rheum 1983;13(2):21227. Crossref

11. Lecouvet FE, van de Berg BC, Maldague BE, Lebon CJ, Jamart J, Saleh M, Noël H, Malghem J. Early irreversible osteonecrosis versus transient lesions of the femoral condyles: prognostic value of subchondral bone and marrow changes on MR imaging. AJR Am J Roentgenol 1998;170(1):71-7. Crossref 
12. Koshino T, Okamoto R, Takamura K, Tsuchiya K. Arthroscopy in spontaneous osteonecrosis of the knee. Orthop Clin North Am 1979;10(3):609-18. https://pubmed.ncbi.nlm.nih. gov/460835/

13. Aglietti P, Insall JN, Buzzi R, Deschamps G. Idiopathic osteonecrosis of the knee. Aetiology, prognosis and treatment. J Bone Joint Surg Br 1983;65-B(5):588-97. Crossref

14. Karim AR, Cherian JJ, Jauregui JJ, Pierce T, Mont MA. Osteonecrosis of the knee: review. Ann Transl Med 2015;3(1):6. Crossref

15. Yates PJ, Calder JD, Stranks GJ, Conn KS, Peppercorn D, Thomas NP. Early MRI diagnosis and non-surgical management of spontaneous osteonecrosis of the knee. Knee 2007;14(2):112-6. Crossref

16. Jureus J, Lindstrand A, Geijer M, Roberts D, Tägil M. Treatment of spontaneous osteonecrosis of the knee (SPONK) by a bisphosphonate. Acta Orthop 2012;83(5):511-4. Crossref

17. Miller GK, Maylahn DJ, Drennan DB. The treatment of idiopathic osteonecrosis of the medial femoral condyle with arthroscopic debridement. Arthroscopy 1986;2(1):21-9. Crossref

18. Akgun I, Kesmezacar H, Ogut T, Kebudi A, Kanberoglu K. Arthroscopic microfracture treatment for osteonecrosis of the knee. Arthroscopy 2005;21(7):834-43. Crossref

19. Forst J, Forst R, Heller KD, Adam G. Spontaneous osteonecrosis of the femoral condyle: causal treatment by early coredecompression. Arch Orthop Trauma Surg 1998;117(1-2):18-22. Crossref

20. Duany NG, Zywiel MG, McGrath MS, Siddiqui JA, Jones LC, Bonutti PM, Mont MA. Joint- preserving surgical treatment of spontaneous osteonecrosis of the knee. Arch Orthop Trauma Surg 2010;130(1):11-6. Crossref

21. Saito $T$, Kumagai $K$, Akamatsu $Y$, Kobayashi H, Kusayama $Y$. Five- to ten-year outcome following medial opening-wedge high tibial osteotomy with rigid plate fixation in combination with an artificial bone substitute. Bone Joint J 2014;96$B(3): 339-44$. Crossref

22. Heyse TJ, Khefacha A, Fuchs -Winkelmann S, Cartier P. UKA after spontaneous osteonecrosis of the knee: a retrospective analysis. Arch Orthop Trauma Surg 2011;131(5):613-7. Crossref

23. Myers TG, Cui Q, Kuskowski M, Mihalko WM, Saleh KJ. Outcomes of total and unicompartmental knee arthroplasty for secondary and spontaneous osteonecrosis of the knee. J Bone Joint Surg Am 2006;88(Suppl 3):76-82. Crossref
24. Woehnl A, Naziri Q, Costa C, Johnson AJ, Mont MA. Osteonecrosis of the knee. Orthop Knowl Online J 2012;10(5).

25. Ficat RP. Idiopathic bone necrosis of the femoral head. Early diagnosis and treatment. J Bone Joint Surg Br 1985;67(1):39. Crossref

26. Jäger M, Tillmann FP, Thornhill TS, Mahmoudi M, Blondin D, Hetzel GR, Zilkens C, Krauspe R. Rationale for prostaglandin 12 in bone marrow oedema --from theory to application. Arthritis Res Ther 2008;10(5):R120. Crossref

27. Lee K, Goodman SB. Cell therapy for secondary osteonecrosis of the femoral condyles using the Cellect DBM System: a preliminary report. J Arthroplasty 2009;24(1):43-8. Crossref

28. Rijnen WH, Luttjeboer JS, Schreurs BW, Gardeniers JWM. Bone impaction grafting for corticosteroid-associated osteonecrosis of the knee. J Bone Joint Surg Am 2006;88(Suppl 3):62-8. Crossref

29. Mont MA, Rifai A, Baumgarten KM, Sheldon M, Hungerford DS. Total knee arthroplasty for osteonecrosis. J Bone Joint Surg Am 2002;84(4):599-603. Crossref

30. Johnson TC, Evans JA, Gilley JA, DeLee JC. Osteonecrosis of the knee after arthroscopic surgery for meniscal tears and chondral lesions. Arthroscopy 2000;16(3):254-61. Crossref

31. Muscolo DL, Costa-Paz M, Ayerza M, Makino A. Medial meniscal tears and spontaneous osteonecrosis of the knee. Arthroscopy 2006;22(4):457-60. Crossref

32. Mac Dessi SJ, Brophy RH, Bullough PG, Windsor RE, Sculco TP. Subchondral fracture following arthroscopic knee surgery. A series of eight cases. J Bone Joint Surg Am 2008;90(5):1007-12. Crossref

33. Pape D, Lorbach O, Anagnostakos K, Kohn D. Osteonecrosis in the postarthroscopic knee. Orthopade 2008;37(11):1099100, 1102-7. Crossref

34. Bonutti PM, Seyler TM, Delanois RE, McMahon M, McCarthy JC, Mont MA. Osteonecrosis of the knee after laser or radiofrequency-assisted arthroscopy: treatment with minimally invasive knee arthroplasty. J Bone Joint Surg Am 2006;88(Suppl 3):69-75. Crossref

35. Pape D, Seil R, Anagnostakos K, Kohn D. Postarthroscopic osteonecrosis of the knee. Arthroscopy 2007;23(4):428-38. Crossref

36. Kraenzlin ME, Graf C, Meier C, Kraenzlin C, Friedrich NF. Possible beneficial effect of bisphosphonates in osteonecrosis of the knee. Knee Surg Sports Traumatol Arthrosc 2010;18(12):1638-44. Crossref 